\title{
The influence of light spectra, UV-A, and growth regulators on the in vitro seed germination of Senecio cineraria DC.
}

\author{
Cristiane Pimentel Victório ${ }^{1, *}$, Nina Cláudia Barbosa da Silva², Maria Apparecida Esquibel ${ }^{3}$, Alice Sato ${ }^{4}$
}

\begin{abstract}
This study was carried out to investigate the effects of light spectra, additional UV-A, and different growth regulators on the in vitro germination of Senecio cineraria DC. Seeds were surface-sterilized and inoculated in MS medium to evaluate the following light spectra: white, white plus UV-A, blue, green, red or darkness. The maximum germinability was obtained using MS0 medium under white light (30\%) and MS + $0.3 \mathrm{mg} \mathrm{L}^{-1} \mathrm{GA}_{3}$ in the absence of light (30.5\%). S. cineraria seeds were indifferent to light. Blue and green lights inhibited germination. Different concentrations of gibberellic acid $\left(\mathrm{GA}_{3}\right)\left(0.1 ; 0.4 ; 0.6 ; 0.8 ; 1.0\right.$ and $\left.2.0 \mathrm{mg} \mathrm{L}^{-1}\right)$ and indole-3-acetic acid IAA $\left(0.1 ; 0.3\right.$ and $\left.1.0 \mathrm{mg} \mathrm{L}^{-1}\right)$ were evaluated under white light and darkness. No concentration of $\mathrm{GA}_{3}$ enhanced seed germination percentage under white light. However, when the seeds were maintained in darkness, $\mathrm{GA}_{3}$ improved germination responses in all tested concentrations, except at $1.0 \mathrm{mg} \mathrm{L}^{-1}$. Under white light, these concentrations also increased the germination time and reduced germination rate. Germination rate, under light or darkness, was lower using IAA compared with GA ${ }_{3}$.
\end{abstract}

Key words: Auxin, gibberellin, light spectra, plant tissue cultures, ultraviolet-A.

\section{RESUMO}

\section{Germinação in vitro de sementes de Senecio cineraria DC.: Efeitos de espectros de luz, UV-A e reguladores de crescimento}

Este estudo foi conduzido para investigar os efeitos dos espectros de luz, adição de UV-A, e diferentes concentrações reguladores de crescimento sobre a germinação in vitro de Senecio cineraria DC. As sementes foram desinfestadas e inoculadas em meio MS para avaliação das seguintes qualidades de luz: branca, branca acrescida de UV-A, azul, verde, vermelha ou ausência de luz. A maior germinabilidade foi obtida usando meio MS0 sob luz branca (30\%) e MS +

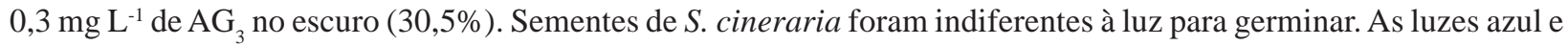
verde inibiram a germinação. Diferentes concentrações de ácido giberélico $\left(\mathrm{AG}_{3}\right)\left(0,1 ; 0,4 ; 0,6 ; 0,8 ; 1,0\right.$ e 2,0 $\left.\mathrm{mg} \mathrm{L}^{-1}\right)$ e ácido indolacético (AIA) $\left(0,1 ; 0,3\right.$ e 1,0 $\left.\mathrm{mg} \mathrm{L}^{-1}\right)$ foram avaliadas sob luz branca e no escuro. Sob luz branca, nenhuma concentração de $\mathrm{AG}_{3}$ aumentou a taxa germinativa. As concentrações de $\mathrm{AG}_{3}$ aprimoraram as respostas de germinação para as sementes mantidas no escuro, exceto na concentração de $1,0 \mathrm{mg} \mathrm{L}^{-1}$. Essas concentrações também aumentaram o tempo médio e reduziram a velocidade de germinação. A taxa de germinação, sob condições de luz e no escuro, foi menor quando se utilizou AIA em comparação com $\mathrm{AG}_{3}$.

Palavras-chave: Auxina, cultura de tecidos vegetais, espectros de luz, giberelina, ultravioleta-A.

Recebido para publicação em fevereiro de 2010 e aprovado em setembro de 2010

${ }^{1}$ Bióloga, Ph. Doctor. Instituto de Biofísica Carlos Chagas Filho, Universidade Federal do Rio de Janeiro, Av. Carlos Chagas Filho, s/n, CCS, Bloco G, 21941-902, Rio de Janeiro, Rio de Janeiro, Brasil. cris.pvictor@gmail.com *Corresponding author.

${ }^{2}$ Bióloga, Ph. Doctor, Departamento de Produção Vegetal, Universidade Federal do Espírito Santo, Alto Universitário, Caixa-Postal16, s/n, 29500-000, Alegre, Espírito Santo, Brasil.ninacbs@pq.cnpq.br.

${ }^{3}$ Licenciada em História Natural, Ph Doctor. Instituto de Biofísica Carlos Chagas Filho, Universidade Federal do Rio de Janeiro, Av. Carlos Chagas Filho, s/n, CCS, Bloco G, 21941902, Rio de Janeiro, Rio de Janeiro, Brasil. esquibel@biof.ufrj.br

${ }^{4}$ Bióloga, Ph Doctor. Departamento de Botânica, Universidade Federal do Estado do Rio de Janeiro, Av. Pasteur 458, 22290-040, Rio de Janeiro, Rio de Janeiro, Brasil. alicesato@unirio.br. 


\section{INTRODUCTION}

Senecio cineraria DC. (syn.: Cineraria maritima L.) (Asteraceae) is a Mediterranean plant widely distributed in cold areas and cultured for ornamental and medicinal purposes (Comes \& Abbott, 2001; Tundis et al., 2005). It is used to treat conjunctivitis, cataracts, corneal opacity, eye ache and inflammatory diseases (Srivastava \& Bagchi, 2006). In Brazil, some industries use this species as raw material for the production of phytomedicines, such as Cineraria eyedrops.

Plant tissue culture is a valuable biotechnological resource that optimizes the production of standardized plant species in a short time. It also guarantees mass production of seedlings and the quality of raw plant material for phytotherapeutic production and ornamental markets. Large-scale production using micropropagation to obtain raw plant material to supply herbalists has recently been studied (Victório et al., 2008; 2010). With this same aim, the present study has established tissue cultures of $S$. cineraria to test the in vitro germination of this species under the effects of different light spectra, UV-A radiation, and hormonal growth factors.

The quality, intensity, direction and duration of light all affect different phenomena in plant development, including seed germination (Victório et al., 2007; Tlig et al., 2008; Victório \& Lage, 2009a; 2009b; 2009c). Phytochrome and cryptochrome families are the main group of photoreceptor proteins responsible for light absorption (Kerbauy, 2008). Classical studies show the effects of red and blue light on germination (Sullivan \& Deng, 2003; Kerbauy, 2008). However, little is known about the effects of UV-A radiation on plant development. Despite the presence of the ozone layer, plants are exposed daily to UV-A which affects their physiological processes. Previous studies showed that UV-A is related to the repair of DNA damage, thereby enhancing photosynthesis and flavonoid production, as well as altering leaf anatomy by the concomitant changes in the thickness of epidermal and parenchyma layers (Wang et al., 2006; Victório et al., 2007).

Different gibberellins are also involved in plant development (Ge et al., 2007). These plant hormones promote germination, supporting the synthesis of specific proteins and mRNA(Bewley, 1997). Additionally, gibberellic acid $\left(\mathrm{GA}_{3}\right)$ may accelerate seed germination of some species by stimulating glucose synthesis, plant hormone production, or by increasing amylolytic activities, an essential stage of seed germination in which á-amylase converts starch to soluble sugar in the endosperm of some seeds (Lonvegrove \& Hooley, 2000; Noguchi, 2008). Our preliminary studies indicated that seed germination of $S$. cineraria was very low under white light conditions or treatment with vernalization periods (Silva et al., 2002). Therefore, to identify the causal factors, this study aimed to study the effects of light spectra and plant hormones on the germinability of S. cineraria.

\section{MATERIAL AND METHODS}

\section{Plant material and seed sterilization}

Senecio cineraria commercial seeds, cultivar Candidíssima, were surface sterilized by immersion in $70 \%$ ethanol (v/v) for $1 \mathrm{~min}$, commercial detergent solution for $15 \mathrm{~min}$, and $30 \%$ commercial sodium hypochlorite (2.3\%) and rinsed with sterile distilled water between treatments. Fractions of seeds from two lots, containing $50 \mathrm{~g}$ each, were used in the experiments. The viability of each lot was about $85 \%$ according to producers.

\section{Tissue cultures}

Seeds were placed in Petri dishes containing $15 \mathrm{~mL}$ of MS medium (Murashige \& Skoog, 1962) supplemented with $30 \mathrm{~g} \mathrm{~L}^{-1}$ of sucrose, $1.3 \mu \mathrm{mol} \mathrm{L}{ }^{-1}$ of thiamine- $\mathrm{HCl}, 3$ $\mu \mathrm{mol} \mathrm{L} \mathrm{L}^{-1}$ of pyridoxine, $4.1 \mu \mathrm{mol} \mathrm{L} \mathrm{L}^{-1}$ of nicotinic acid, 0.6 mmol L-1 of myo-inositol and solidified with $7.8 \mathrm{~g} \mathrm{~L}^{-1}$ agar, $\mathrm{pH}$ rated to $5.8 \pm 0.1$, then sterilized in an autoclave at 120 ${ }^{\circ} \mathrm{C}$ and $1.1 \mathrm{Kgf} \mathrm{cm}^{-2}$. Seeds were kept in a growth room at $25 \pm 2{ }^{\circ} \mathrm{C}$ in the dark or light under a photoperiod of 16 hours. Light intensities were measured by a quantameter (Biospherical Instruments Inc., QSL-100). Darkness was ensured by wrapping the Petri dishes in two layers of aluminum foil. All treatments were arranged in a completely randomized design with four replicates of 25 seeds per treatment.

\section{Treatment with light spectra and growth regulators}

White light plus UV-A was tested using MS0 (control) and $\mathrm{MS}+0.3 \mathrm{mg} \mathrm{L}^{-1}$ of $\mathrm{GA}_{3}$. The chosen concentration was based on previous results with $S$. cineraria tissue cultures (Silva, 2001). Light intensities varied from 14 to $20 \mathrm{ì} \mathrm{mol} \mathrm{m} \mathrm{m}^{-2} \mathrm{~s}^{-1}$, and one lamp per shelf was used for each light spectrum. Light spectra were obtained from one fluorescent lamp (Sylvania ${ }^{\circledR}, 20 \mathrm{~W}$ T 12) in white (control, $20 \mathrm{ì} \mathrm{mol} \mathrm{m} \mathrm{m}^{-2} \mathrm{~s}^{-1}$ ), blue (17 ì mol m $\mathrm{m}^{-2} \mathrm{~s}^{-1}$ ), green (14 ì mol m ${ }^{2} \mathrm{~s}^{-1}$ ) and red (14 ì mol m-2 $\mathrm{s}^{-1}$ ) (Figure 1 ). Treatment with white light supplemented by ultraviolet A (UV-A) was adjusted to provide the same light intensity of white light (20 ì mol m² s-1).

The effects of different concentrations of $\mathrm{GA}_{3}(0.0$ (MS0 - control); 0.1; 0.3; 0.4; 0.6; 0.8; 1.0 and $2.0 \mathrm{mg} \mathrm{L}^{-1}$ ) and IAA (indole-3-acetic acid) (0.0 (control); 0.1; 0.3 and $1.0 \mathrm{mg} \mathrm{L}^{-1}$ ) were evaluated. Both hormonal treatments were conducted under white light (20 ìmol m $\left.\mathrm{m}^{-2} \mathrm{~s}^{-1}\right)$ and in the dark. 
Seeds maintained under light were evaluated every day for five weeks, recording the percentage of germination, average germination time (days) and average germination rate $\left(\right.$ days $\left.^{-1}\right)$. The average germination rate and average germination time were calculated according to Labouriau (1983). Seeds placed in the dark were evaluated after five weeks. Germination was considered to have occurred when the radicle protruded through the seed.

\section{Statistical analysis}

Data were analyzed in a completely randomized design using the Statistica ${ }^{\circledR} 6.0$ program. The Least Significant Difference (LSD) at 5\% probability level was used to test differences between germination percentage means.

\section{RESULTS AND DISCUSSION}

At the end of five weeks, the application of UV-A was not found to affect the germination percentage of seeds when compared with white light (control) in either medium. However, difference was found in mean germination time. Under white light plus UV-A, germination started during the first week using MS0 and during the second week using MS + $\mathrm{GA}_{3} 0.3 \mathrm{mg} \mathrm{L}^{-1}$, compared with white light treatment alone, indicating that additional UV-A induced germination more rapidly compared with other treatments. Addition of UV-A and $\mathrm{GA}_{3}$ medium in combination did not produce significantly different responses in germination compared with MS0 under white light (Figure 2A-B).

Red light is considered as a stimulus for germination of several seeds that show positive photoblastic behavior. In addition, seeds require white or red light to reach maximum germinability (Figueroa et al., 2007). However, in the present study, red light was not effective in improving $S$. cineraria in vitro germination (Figure 2A).

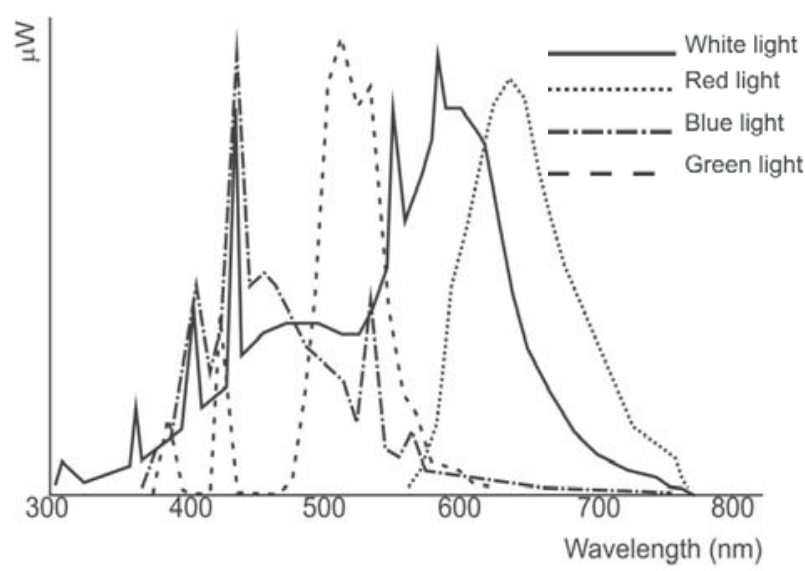

Figure 1. Spectral power distributions of used light sources (data provided by the Sylvania supplier).
It should be noted that works evaluating green light on plant development have only just emerged in the literature (Islam et al., 1999). However, in this study, it was found that germination percentage under green light was significantly smaller than white light, in MS0 (Figure 2A). Islam et al. (1999) also reported low in vitro germination of Cattleya walkeriana under green light. This kind of light is used as security light in germination experiments. It was also found that germination percentages under red and green lights were very similar over the five-week experimental period. Under green light, these data indicate that seed germination may occur.

Seeds maintained in MS0 showed low germination under blue light (Figure 2). This finding agrees with results presented by Gopal \& Sharma (1983) who described the inhibitory effect of blue light in Typha angustata seed germination. Interestingly, the same plant photoreceptors absorb blue light and UV-A (Sulllivan \& Deng, 2003). The
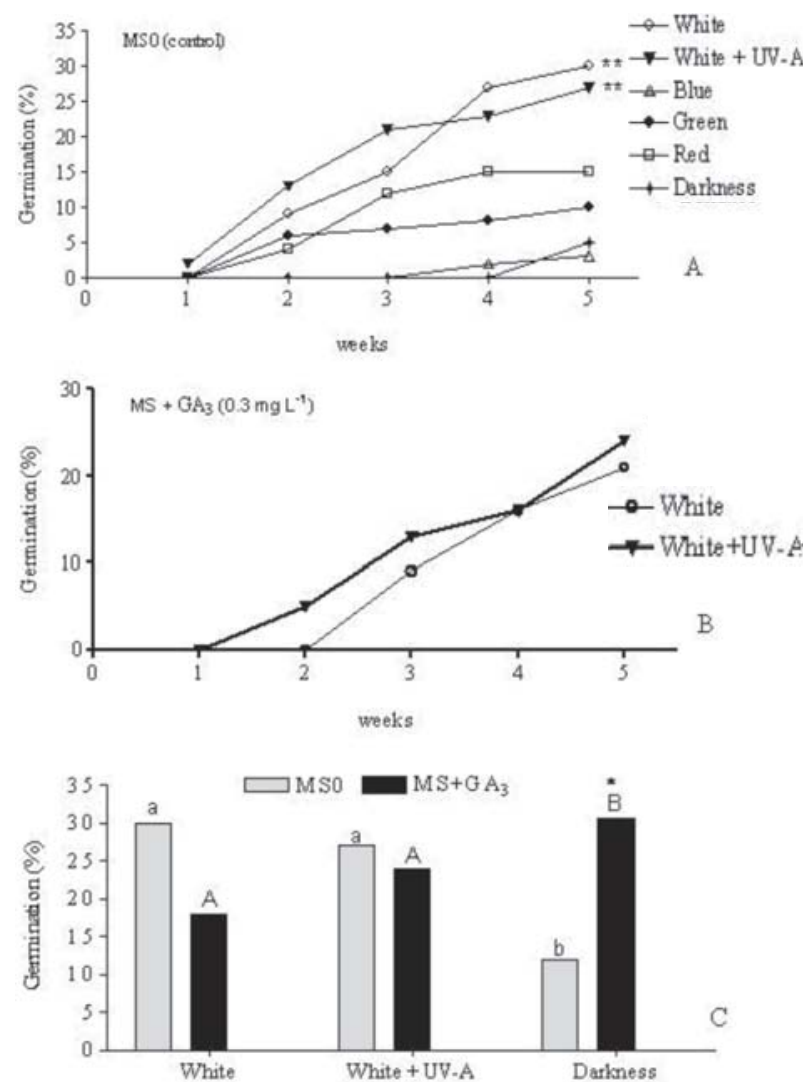

Figure 2. In vitro germination of Senecio cineraria DC. for five weeks under different light spectra and in the dark: A. MS0 (control), B. MS + GA $0.3 \mathrm{mg} \mathrm{L}^{-1}$. C. 5-week in vitro germination comparing MS0 and MS + GA $0.3 \mathrm{mg} \mathrm{L}^{-1}$ media under white light, UV-A supplementation and dark. Different letters indicate significant differences. Lower case letters compare the effects of light on seeds kept in MS0 medium. Upper case letters compare light spectra using $\mathrm{MS}+\mathrm{GA}_{3} 0.3 \mathrm{mg} \mathrm{L}^{-1}$. **Indicates statistical differences compared with blue and dark (A). *Indicates statistical differences between culture media (MS0 and MS + GA $A_{3}$ ) for each light spectrum (C), ( $\mathrm{p} £$ 0.05, 100 seeds/treatment). 
results of the present study could shed light on this seeming paradox in that the absorption of these spectra by cryptochromes induce different responses, as also mentioned by Gyula et al. (2003), since results for $S$. cineraria seeds under blue light and UV-A were completely different. Compared to white light, all other light spectra showed a reduction of seed germination of S. cineraria, suggesting an inhibition of photoreceptors. The effect of $\mathrm{GA}_{3}$ was not found to improve under white light + UV-A compared with MS0 (Figure 2B).

Experiments were performed under both light and dark, using different $\mathrm{GA}_{3}$ concentrations. Under white light, results showed that $\mathrm{GA}_{3}$ did not improve the germination percentage (Figure 3). Although germination time increased under white light, germination rate was reduced to 0.6 and $0.8 \mathrm{mg} \mathrm{L}^{-1}$ of $\mathrm{GA}_{3}$ (Figure $3 \mathrm{~A}-\mathrm{B}$ ). In contrast to a
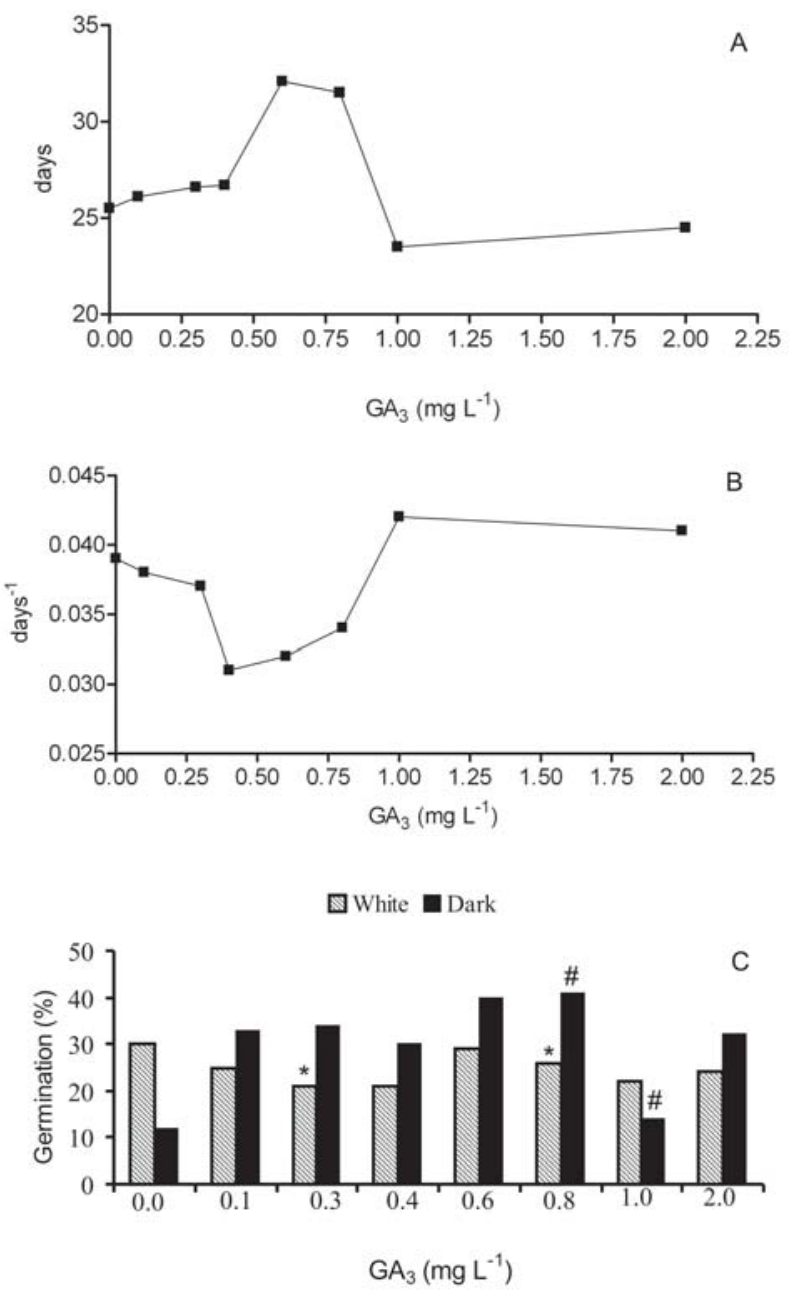

Figure 3. Senecio cineraria DC. mean time and mean rate of germination under white light in different $\mathrm{GA}_{3}$ concentrations (mg L ${ }^{-1}$ ) over 5 weeks. A. Mean time; B. Mean rate; C. Total germination under white light and in the dark. *Indicates differences between white light and dark, considering each concentration in $\mathrm{mg} \mathrm{L}^{-1}$. \#Indicates statistical differences among concentrations, considering the dark control ( $\mathrm{p} £ 0.05,100$ seeds/ treatment). generally low germination rate induced by $\mathrm{GA}_{3}$ in any concentration under light conditions, all concentrations of $\mathrm{GA}_{3}$, except $1.0 \mathrm{mg} \mathrm{L}^{-1}$, induced a higher germination rate in the dark. Higher $\mathrm{GA}_{3}$ concentrations did not correspond to an increase of germination percentage (Figure 3C).

The highest germination percentage (a maximum 10 percent point increase compared with control medium) was obtained using 0.6 and $0.8 \mathrm{mg} \mathrm{L}^{-1}$ of $\mathrm{GA}_{3}$, but in the dark (Figures 2C and 3C). This result can most likely be explained by the replacement of light by $\mathrm{GA}_{3}$, which is necessary to stimulate photoreceptors and, consequently, the synthesis of gibberellins involved in germination (Toyomasu et al., 1998). Gibberellins have a well-known role in seed germination induction. In fact, $\mathrm{GA}_{3}$ may be used as a means of breaking dormancy. However, according to Baskin \& Baskin (2001), no seed dormancy was reported for S. cineraria. Moreover, based on germination studies of $S$. vulgaris, Lutman et al. (2008) found only limited results of dormancy in the dark. Finally, Silva et al. (2002) carried out studies using vernalization periods (1, 5, 15, 30 and 60 days) and observed that the germination of $S$. cineraria was less than $16 \%$. Similarly, we found only limited germination of $S$. cineraria seeds under dark conditions with no treatment. Importantly, however, when seeds were treated with $\mathrm{GA}_{3}$ in the dark, we found, as noted above, a higher rate of germination than the same concentrations of $\mathrm{GA}_{3}$ in the light. Therefore, it can be conclude that $\mathrm{GA}_{3}$ is instrumental in breaking dormancy. Studies have shown that IAA is involved in the early stages of germination (Slavov et al., 2004). Germination tests using IAA indicated that there was no increase in S. cineraria germinability, either in the light or dark, in comparison with MS0 medium. Moreover, under dark conditions, the germination rate was lower with the addition of IAA compared with white light (Figure 4) and therefore different from results found for $\mathrm{GA}_{3}$ (Figure 3).

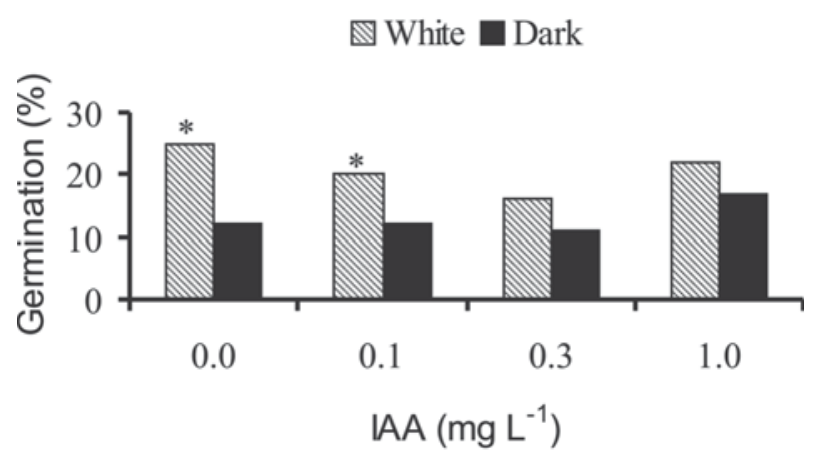

Figure 4. Senecio cineraria DC. germination using different IAA concentrations in $\mathrm{mg} \mathrm{L}^{-1}$, after 5 weeks. ${ }^{*}$ Indicates statistical differences between white light and dark ( $\mathrm{p}<0.05,100$ seeds/ treatment).

Rev. Ceres, Viçosa, v. 57, n.5, p. 576-580, set/out, 2010 


\section{CONCLUSION}

The presented data showed a higher germinability of S. cineraria under light conditions compared with dark, but germination percentage was low which may be related to other parameters, such as temperature, an important determinant of seed germination. The addition of $\mathrm{GA}_{3}$ enhanced seed germination in the absence of light.

Seeds of $S$. cineraria respond more to any light exposure when compared with dark, although the influence of the photoreceptors in germination seemed very slight by the few changes in different light spectra.

White light and white light supplemented with UV-A gave the best responses to in vitro germination using MS0 medium.

\section{ACKNOWLEDGMENTS}

In memoriam to our dear laboratory technician, Mr. Valter Pereira Rodrigues. The authors wish to thank CAPES, FINEP and the Laboratório Simões Ltda. for financial support.

\section{REFERENCES}

Baskin CC \& Baskin JM (2001) Seeds - Ecology, biogeography, and evolution of dormancy and germination. 1 ed. San Diego, Academic Press. 666p.

Bewley JD (1997) Seed Germination and dormancy. The Plant Cell, 9:1055-1066.

Comes HP \& Abbott RJ (2001) Molecular phylogeography, reticulation, and lineage sorting in Mediterranean Senecio sect. Senecio (Asteraceae). Evolution, 55:1943-1962.

Figueroa R, Doohan D, Cardina J \& Harrison K (2007) Common groundsel (Senecio vulgaris) seed longevity and seedling emergence. Weed Science, 55:187-192.

Ge L, Peh CY, Yong JW, Tan SN, Hua L \& Ong ES (2007) Analyses of gibberellins by capillary electrophoresis-mass spectrometry combined with solid-phase extraction. Journal of Chromatography A, 1159: 42-249.

Gopal B \& Sharma KP (1983) Light regulated seed germination in Typha angustata Bory et Chaub. Aquatic Botany, 16:377-384.

Gyula P, Schafer E \& Nagy F (2003) Light perception and signalling in higher plants Current Opinion in Plant Biology, 6:446-452.

Islam MO, Matsui S \& Ichihashi S (1999) Effects of light quality on seed germination and seedling growth of Cattleya orchids in vitro. Journal of the Japanese Society for Horticultural Science, $68: 1132$ - 1138 .

Kerbauy GB (2008) Fisiologia Vegetal. 2. ed. Rio de Janeiro, Guanabara Koogan S.A. 431p.

Labouriau LGA (1983) A germinação de Sementes. Washington, Secretaria Geral da Organização dos Estados Americanos. 174p.

Lonvegrove A \& Hooley R (2000) Gibberellin and abscisic acid signalling in aleurone Trends in Plant Science, 5:102-110.

Lutman PJW, Berry KJ \& Freeman SE (2008) Seed production and subsequent seed germination of Senecio vulgaris (groundsel) grown alone or in autumn-sown crops. Weed Research, 48:237-247.
Murashige T \& Skoog F (1962) A revised medium for rapid growth and bioassays of tobacco tissue cultures. Physiology Plantarum, 15:473-497.

Noguchi HK (2008) Effects of four benzoxazinoids on gibberellininduced á-amylase activity in barley seeds. Journal of Plant Physiology, 165:1889-1894.

Silva NCB (2001) Senecio cineraria (DC): abordagens biofísica e biotecnológica na obtenção de um produto fitoterápico. Dissertação de Mestrado. Universidade Federal do Rio de Janeiro, Rio de Janeiro, 117p.

Silva NCB, Victório CP, Lage CLS \& Esquibel MA (2002) Tratamentos de pré-resfriamento associado à adição do fitorregulador $\mathrm{GA}_{3}$ na germinação in vitro de Senecio cineraria. In: XVII Simpósio de Plantas Medicinais do Brasil, Cuiabá. Anais, SPMB. p.123.

Slavov S, van Onckelen H, Batchvarova R, Atanassov A \& Prinsen E (2004) IAA production during germination of Orobanche spp. seeds. Journal of Plant Physiology, 161: 847-853.

Srivastava NK \& Bagchi GD (2006) Influence of micronutrient availability on biomass production in Cineraria maritima. Indian Journal of Pharmaceutical Science, 68:238-239.

Sullivan JA \& Deng XW (2003) From seed to seed: the role of photoreceptors in Arabidopsis development. Developmental Biology, 260: 289-297.

Tlig T, Gorai M \& Neffati M (2008) Germination responses of Diplotaxis harra to temperature and salinity. Flora, 203:421428.

Toyomasu T, Kawaide H, Mitsuhashi W, Inoue Y \& Kamiya Y (1998) Phytochrome regulates gibberellins biosynthesis during germination of photoblastic lettuce seeds. Plant Physiology, 118:1517-1523

Tundis R, Passalacqua NG, Peruzzi L, Statti GA, Bonesi M, Loizzo MR, Conforti F, Cesca G \& Menichini F (2005) Comparative chemical variability of the non-polar extracts from Senecio cineraria group (Asteraceae). Biochemical Systematics and Ecology, 33:1071-1076.

Victório CP, Henriques AB, Tavares ES, Esquibel MA \& Lage CLS (2010) Standardized production of Phyllanthus tenellus Roxb. by plant tissue culture. Revista Ciência Agronômica, 41:272278.

Victório CP, Kuster RM \& Lage CLS (2007) Anatomia de plantas de Phyllanthus tenellus Roxb. cultivadas in vitro sob diferentes qualidades de luz. Brazilian Journal of Biosciences, 5:216-218.

Victório CP \& Lage CLS (2009a) Efeitos da qualidade de luz na germinação e desenvolvimento inicial in vitro de Phyllanthus tenellus. Revista Ciência Agronômica, 40: 400-405.

Victório CP \& Lage CLS (2009b) Effects of light quality and plant growth regulators on in vitro flowering of Phyllanthus tenellus Roxb. General and Applied Plant Physiology, 35:44-50.

Victório CP \& Lage CLS (2009c) Germinação e desenvolvimento pós-germinativo in vitro de Calendula officinalis L. sob diferentes qualidades de luz. Revista de Biologia e Farmácia (BioFar), 1:81-87.

Victório CP, Sato A, Esquibel MA \& Lage CLS (2008) Sucrose on in vitro cultures of Calendula officinalis L. Plant Cell Culture \& Micropropagation, 4:34-41.

Wang Y, Zhang N, Qiang W, Xiong Z \& Du G (2006) Effects of reduced, ambient, and enhanced UV-B radiation on pollen germination and pollen tube growth of six alpine meadow annual species. Environmental and Experimental Botany, 57: 296-302. 